UDC 81 27; IRSTI 2643-9

https://doi.org/10.47526/habarshy.vi1.395

\author{
A.B. PIYAZBAYEVA* \\ PhD Doctoral Student, A. Baitursynov Institute of Linguistics \\ (Kazakhstan, Almaty),e-mail: aqmaral.piyazbay@tilbilimi.kz \\ https://orcid.org/0000-0001-9180-8010
}

\title{
THE LANGUAGE SITUATION OF KAZAKHSTAN: SOCIOLINGUISTIC ANALYSIS
}

Language is a social phenomenon that exists in human society. Any language the Society performs communicative (means of communication), expressive (means of revealing thoughts), constructive (means of thinking), accumulative (skills acquired from experience and knowledge), cumulative (accumulation), transformative (transfer), etc. These are the main functions of the language, which are inherent in different levels of development at different stages and are innate components that do not change in their own system. In addition, the social functions of the language are a reflection of the use and use of the same basic functions of the language in different social environments, spheres of public life, and in different purposes and situations. The factors influencing the formation of the public environment in the Kazakh language are the system of Education, Culture, mass media, departments and departments of language development in each institution that monitor the conduct of office work in the state language, etc. institutions and public organizations, as well as the state authorities themselves. At the same time, the problem of the language situation in modern Kazakhstan is reflected in the address of the head of State N.A. Nazarbayev "New Kazakhstan in the new world" in 2009, where in order to ensure the competitiveness of the country and its citizens, it is proposed to gradually implement the cultural project "trinity of languages" in accordance with the need to develop trilingualism, i.e. Kazakh as the state language, Russian as the language of International Communication, and English as the language of successful integration into the global economy.

In this regard, a number of scientific studies are currently underway to study and analyze the social problems of the Kazakh language. In terms of the language reform associated with the transition to a new alphabet in Kazakhstan, it is particularly relevant to republishing and defining the viable parameters of the language.

Keywords: vitality of the language, Kazakh language content, linguistic space, the language situation, model of the Kazakh language.

А.Б. ПИЯЗБАЕВА

PhD докторант, A. Байтұрсынұльг атындавы Тіл білімі институты (Қазақ̧стан, Алматы қ̧.), е-mail: aqmaral.piyazbay@tilbilimi.kz.

\section{Қазіргі Қазақстанның тілдік жағдаяты: әлеуметтік-лингвистикалық талдау}

Тіл - адамзат қоғамында өмір сүретін әлеуметтік құбылыс. Кез келген тіл қоғамда коммуникативтік (қарым-қатынас құралы), экспрессивтік (ойды жарыққа шығару құралы), конструктивтік (ойлау құралы), аккумулятивтік (тәжірибе мен білімнен жиналған дағды),

\footnotetext{
*Бізге дұрыс сілтеме жасаңыз:

Piyazbayeva A.B. The Language Situation of Kazakhstan: Sociolinguistic Analysis // Яcayu университетінің хабаршысы. $\quad$ - 2021. $\quad$ №1 (119). $\quad$ - $\quad$ Б. 220-228. https://doi.org/10.47526/habarshy.vi1.395

*Cite us correctly:

Piyazbayeva A.B. The Language Situation of Kazakhstan: Sociolinguistic Analysis // Iasaýl ýnıversitetiniń habarshysy. - 2021. - №1 (119). - B. 220-228. https://doi.org/10.47526/habarshy.vi1.395
} 
кумулятивтік (жинақтау), трансформациялық (тасымалдау) және т.б. қызметтер атқарады. Бұлар тілдің түрлі кезеңдеріндегі даму деңгейлеріне тән және өзіндік жүйесінде өзгермейтін туабітті компоненттері болып табылатын негізгі қызметтері деп аталады. Ал тілдің қоғамдық қызметтері, бұл - тілдің сол негізгі қызметтерінің әртүрлі әлеуметтік орталарда, қоғамдық өмір салаларында және әртүрлі мақсаттар мен жағдаяттарда пайдаланылуы қолданылуының көрінісі. Қазақ тілінде қоғамдық ортаны қалыптастыруға ықпал ететін факторлар білім беру жүйесі, мәдениет, бұқаралық ақпарат құралдары, мемлекеттік тілде іс жүргізуді бақылауды жүзеге асыратын әрбір мекемедегі тілді дамыту бөлімдері және басқа да мекемелер мен қоғамдық ұйымдар, сондай-ақ мемлекеттік билік органдарының өздері болып табылады. Сонымен қатар, қазіргі Қазақстандағы тілдік ахуал проблемасы Елбасы Н.Ә. Назарбаевтың 2009 жылғы «Жаңа әлемдегі жаңа Қазақстан» Жолдауында көрініс тапты. Онда елдің және оның азаматтарының бәсекеге қабілеттілігін қамтамасыз ету мақсатында үштілділікті дамыту қажеттілігіне сәйкес «Тілдердің үштұғырлығы» мәдени жобасын кезең-кезеңімен іске асыру ұсынылады: мемлекеттік тіл ретінде қазақ тілі, ұлтаралық қатынас тілі ретінде орыс тілі және әлемдік экономикаға ойдағыдай кірігу тілі ретінде ағылшын тілі. Осыған байланысты қазіргі уақытта қазақ тілінің әлеуметтік мәселелерін зерделеу және талдау бойынша бірқатар ғылыми зерттеулер жүргізілуде. Қазақстандағы жаңа әліпбиге көшуге байланысты тілдік реформа жағдайында тілдің өміршең параметрлерін қайта басып шығару және анықтау ерекше өзекті болып табылады.

Бұл мақалада қазіргі Қазақстанның тілдік жағдаятына әлеуметтік-лингвистикалық талдау жасалған.

Кілт сөздер: тілдің өміршеңдігі, қазақтілді контент, тілдік кеңістік, тілдік қайшылықтар, тіл жағдаят, тілдің әлеуметтік функциялары, қазақ тілінің моделі, мемлекет құрушы ұлт.

\section{А.Б. ПИЯЗБАЕВА}

PhD докторант, Институт языкознания имени А. Байтурсынова (Казахстан, г. Алматы),e-mail: aqmaral.piyazbay@tilbilimi.kz

\section{Языковая ситуация современного Казахстана: социолингвистический анализ}

Язык - социальное явление, существующее в человеческом обществе. Любой язык в обществе выполняет коммуникативную (средство общения), экспрессивную (средство раскрытия мысли), конструктивную (средство мышления), накопительную (навыки, приобретенные из опыта и знаний), кумулятивную (накопление), преобразующую (передача) и др. функции. Это основные функции языка, которые присущи разным уровням развития на разных этапах и являются врожденными компонентами, не изменяющимися в собственной системе. А социальные функции языка - отражение использования и использования одних и тех же основных функций языка в различных социальных средах, сферах общественной жизни, в различных целях и ситуациях. Факторами, влияющими на формирование общественной среды на казахском языке, являются система образования, культура, средства массовой информации, отделы развития языка в каждом учреждении, осуществляющие контроль за ведением делопроизводства на государственном языке и др. учреждения и общественные организации, а также сами органы государственной власти. В то же время проблема языковой ситуации в современном Казахстане нашло отражение в Послании Елбасы Н.А. Назарбаева «Новый Казахстан в новом мире» 2009 года, где в целях обеспечения конкурентоспособности страны и ее граждан предлагается поэтапно реализовывать культурный проект «триединство языков» в соответствии с необходимостью развития трехъязычия: казахского как государственного языка, русского как языка межнационального общения и английского как языка успешной интеграции в мировую 
экономику. В связи с этим в настоящее время проводится ряд научных исследований по изучению и анализу социальных проблем казахского языка. В условиях языковой реформы, связанной с переходом на новый алфавит в Казахстане, особенно актуально переиздание и определение жизнеспособных параметров языка.

В данной статье дан социолингвистический анализ языковой ситуации современного Казахстана.

Ключевые слова: жизнеспособность языка, казахское языковое содержание, языковое пространство, языковые противоречия, языковая ситуация, социальные функции языка, модель казахского языка, государствообразующая нация.

\section{Introduction}

The viability of the language. In the course of the development of sociolinguistic monitoring as a scientific criteria for the provision of multilingual education based on the definition of the criterion (criterion) of examination of language situations in accordance with quantitative, qualitative and evaluative features, a number of scientific studies on the study, analysis of social problems of the Kazakh language [1;2], still requires great attention. From the point of view of the language reform associated with the transition to a new alphabet in Kazakhstan, it is especially important to reissue and determine the viable parameters of the language.

The vitality of language (lat. vitalis - viable) - the ability of language to the existence, development, tendency, flexibility. The viability of a language is measured by a combination of the following objective and subjective indicators:

1. General provisions: Socio-political indicator, including the implementation of targeted language policy in the language status and corpus planning, the presence of a clear state program for the development and support of the language, the development of social infrastructure that ensures the full functioning of the language (educational institutions, print networks, television and radio companies and television programs, publishing, etc.);

2. Socio-demographic indicator: including the number of speakers in the same language within the state in relation to other language groups, among the total number of this ethnic group, the number of users of the language (the number of speakers as a native) among young people, the number of monolinguts and bilinguals in the same language, the degree of bilingual speakers, etc.;

3. Linguistic indicator, including the presence of a literary language, normalization and stability of the language norm, the speed of distribution of language updates, the ability to resist foreign language influence, the presence of industry terminology system, the dynamics of vocabulary, etc.;

4. Social and functional indicators-this is measured by the use of the social service of language in the most important areas of society, including education (formation in the main areas of language competence), science (humanitarian and natural-technical), the media, administrative activities and records management, legal proceedings, industrial enterprises and other areas of production;

5. National and cultural indicators, including in national art, theater, cinema, DDU, in various types of literature (fiction, lexicography, religious, business, educational, terminological, etc.) b. the level of language use and the presence of ritual traditions, etc.

In the research studies of such scientists like Uali, Suleymenova, Akhmetzhanova have been stated the state of the Kazakh language and viability of the language [3; 4]. The scholars demonstrated many scientific reasons defining the main features and parameters of the viability of the language. Besides, as the main sign of viability of the Kazakh language based on modern political, cultural, social sources it is possible to allocate the following:

1) growth of national consciousness and assessment of national values;

2) availability of national culture and National literature; 
3) improving the social service of the state language in various spheres of life;

4) free speech of children under 10 years in the state language;

5) in the context of modern trilingualism, special attention was paid to the expansion of the state language in society, the creation of conditions for the education of children and school-age children in the state language;

6) the priority of language policy in connection with the transition from brass to the new national alphabet (reprinting of textbooks of the Kazakh language with a new alphabet, updating the content of the scientific course of the Kazakh language, the regulation of onomastic space in the process of reprinting the Latin alphabet, the national character, the standardization of the terminal system).

\section{Review of Literature}

Language is a social phenomenon living in human society. Any language in society should be communicative (means of communication), expressive (means of thought illumination), constructive (means of thinking), accumulative (accumulated experience and knowledge), cumulative (accumulated), transformational (portable), etc. performs functions. They are called the basic functions characteristic of the various stages of language development and are innate components that do not change in their own system. Besides, the social functions of language are a reflection of the use and use of these basic functions of language in different social environments, spheres of public life and for different purposes and situations. Factors affecting the formation of the social environment in the Kazakh language-departments and departments of language development in each institution, controlling the conduct of business in the state language and the media system of education, culture, etc. b. institutions and public organizations, as well as directly state power. According to the results of measures for the development of the state language in the system of periodic and electronic media, the dynamics of growth of the Kazakh-language environment from year to year increases, but the language environment in the office and public service, private enterprise, private organizations has radically changed to the Kazakh language.

Model of the Kazakh language at the social level in modern Kazakhstan:

1) Kazakh language - native, state language, language of communication with representatives of other nationalities in the country, language of information through the media, the basic language for learning Russian and English;

2) Kazakh language for a small part (Russian) of the state nation-the language of the nation, the state language;

3) Kazakh language for representatives of the large Diaspora (Russian ethnos) in Kazakhstan - the language of the state, the state language, partly the language of communication with representatives of other nationalities and information through the media;

4) Kazakh language for representatives of other nationalities in Kazakhstan is the basic language for learning the state language, the state language, partly the language of communication and communication with representatives of other nationalities, the language of information through the media, partly other languages [5].

The language space using the state language is determined on the basis of such a diverse linguistic community in Kazakhstan. Language space is formed depending on the language in which citizens live. From this point of view, there are several language environments in the language space of Kazakhstan. They are the Kazakh-speaking space, Kazakh-Russian-speaking space, Russian-speaking space and little-Russian-English space. In addition, the country has language spaces of diasporas with a smaller number. However, the modern language space is characterized by the activity of the Kazakh, Russian and English languages. The social sphere of the widely used environment of the Kazakh language is the middle, that is, the most widely used language among the vulnerable, middle-social citizens of society in the social hierarchy. This group includes residents who are remote from the economic and financial elite of society, groups of political 
influence: teachers, middle and Junior employees working in various offices, representatives of small trade, builders, employees, pensioners, drivers, etc. 2). Of course, Kazakh-speaking citizens are not few In power, national companies, at the best jobs. However, most of them are working languages, the language of the environment-Russian. That is, the space of the Kazakh language in society is quite liquid, authoritative, inactive. Therefore, there are often cases when pure Kazakhspeaking can not affect the social transformation, social changes in their native language.

The modern language situation and the state of the Kazakh language. The language situation in Kazakhstan is determined on the basis of the following social linguistic parameters:

- first of all, the language situation is exoglossal nature, as it consists of many languages, functions are not the same in different public spheres;

- secondly, from the point of view of distribution and functionality are bilingual in nature: from the legal point of view, the Kazakh language is the state language, however, despite a trend of strengthening the role of the Kazakh language in international communication and the official sphere, the role of the Russian language with the inertia of the efforts of politicians of the Soviet period for some functional areas show significant priority;

- thirdly, multilingualism is spreading, which is unequal, because in some spheres of communication the scope of the Russian language is still extensive, wider than the Kazakh;

- fourth, the extralinguistic motives influencing the language have not stopped changing [6].

However, at present, the statistics confirm the positive trends reflecting the strengthening of the social status of the Kazakh language.

Today, in independent Kazakhstan, the creation of optimal socio-linguistic space is built through the phased implementation of language policy. Significantly expanded the infrastructure of teaching the state language:

- kindergartens with the Kazakh language of instruction - 5962 (an increase of 34\% compared to 2001), schools - 5362 (an increase of 53\% compared to 2001), 101 state language training centers were established. Dominated by a network of rural schools ( 76.3 per cent). At the same time, the contingent of urban and rural schools is almost equal (village $-47.5 \%$, city $-52.5 \%$ ). At the end of the 2017 academic year, the number of graduates who studied in the Kazakh language, including Kazakh schools and mixed schools, increased by 60128 . This is $72.2 \%$ of the total number of school graduates. The number of students trained in Russian is 23134, i.e. $27.8 \%$. In addition, the number of graduates who scored from 101 to 125 points was 10491 . The number of Russian-speaking graduates who have achieved such high results-3976 [7];

The process of translation of office work into the state language is actively implemented (the share of documents in the Kazakh language in state bodies is about 67\%) [7].

The level of knowledge of the state language by adult citizens. According to system evaluation level of Kazakh language proficiency QAZTEST in 2017, the KazTest system testing were 94 578. Among the participants tested, the bulk of the participants in paper format (computer testing - 19,296 people) were 29,458 (39.1\%) - public sector employees, 22,837 (30.4\%) - civil servants, 12,484 (16.6\%) - military personnel, 9,438 (12.5\%) - employees of non-governmental institutions, $515(0.7 \%)$ - candidates for the Bolashak scholarship and $550(0.7 \%)$ - employees of other fields.From January 2 to December 28, 2017, the number of civil servants who took part in the assessment and determination of the level of Kazakh language proficiency under the KazTest system amounted to 29458 people. The share of employees of organizations providing public services, owning on the basis of testing at the level of B1-48\%; the share of employees of organizations providing public services, owning at the level of C1-1.03\%. In 2017, all Central Executive bodies were tested, with the exception of the Ministry of culture and sports of the Republic of Kazakhstan, the Ministry of religious Affairs and civil society. The number of participants in the test to assess the level of proficiency in the state language under the KazTest system increased by 20,846 people compared to 2016 . This year, the number of participants among social groups has increased. 
"Soros - Kazakhstan" financial/expert support Fund held in "how are you living, young people?" according to the report prepared by the results of the survey among young people "ethnoreligious identity of regional youth", from April 23 to May 6, 2016 within the research project Of the Association of sociologists and political scientists of Kazakhstan (Kao), the level of knowledge of the state language among the country's youth is as follows: $100 \%$ of Kazakhs speak the Kazakh language, 33.7\%-in other ethnic groups, 5\% - among Russians. However, among the Russianspeaking Kazakhs was not a single person who is fluent in the Kazakh language. Mainly Kazakh ethno-linguistic areas are the Western (85.8\%), South (74.7 percent) and Eastern (57.8 per cent). Most Russian people who can explain in Kazakh and understand individual expressions are 70.2\% Russian Kazakhs, $53.8 \%$ Russian, and $41 \%$ of other nationalities. In terms of regions, the indicator of poor state language proficiency in the West of the country is dominated by $8.2 \%$ and in the center $-36.9 \%$. The Russians (38.8 per cent) are the largest number of people who do not speak the state language, the representatives of other ethnic groups (22.3 per cent) and the Russian Kazakhs (14.5 per cent) are the smallest. The regions of concentration that do not speak the state language are the North $(27.3 \%)$ and East $(21.9 \%)$ of the country.

Contradictions in the state language. The main contradiction is the lack of desire to master the state language among the hard of hearing, unable to self-esteem and absolutely do not know (on average $-55.1 \%$ ). Among the isolated population level is not adopted, the state language is above average among Russian (62.4\%) and other ethnic groups (60.1 per cent) and the Russian (38.2 per cent) - below. At the regional breakdown, the share of those unwilling to learn the state language varies in the East from 29.6 per cent to 76.7 per cent in the West.

The main language of communication. The data obtained show that there is a bilingualism in Kazakhstan. Russian-speaking youth in the majority of cases prefers to speak in Russian. Russian is the language of communication of $86.7 \%$ of Russians, $72.3 \%$ of Russian Kazakhs, $51.2 \%$ of representatives of other ethnic groups. The region where Russian ethnic groups predominate is Northern $(52.5 \%)$ and Central $(47.7 \%)$. In other regions, the highest rate of communication in Russian is in the East (42.2\%), the lowest - in the West (7.3\%). The experience of Kazakh-speaking Kazakhs determines high tolerance to bilingualism. Among them, the main language of communication is Kazakh and Russian $(58.3 \%)$ at the same level. In the context of the double ratio prevails in the East (48.4 per cent), the West (47\%) and the South (47.6 per cent) of the country. Kazakh language is mainly spoken by Kazakh - speaking Kazakhs (39\%): 44\% - in the West and $35.3 \%$ - in the South. Kazakh Russian is rarely used by other ethnic groups (10.2\%), Russian Kazakhs (7.9\%) and Russians (1.3\%) [8].

According to Astana maslikhat data of December 11, 2015 "Astana city development program for 2016-2020", it was established that the share of the adult population in Astana who speaks the state language is $81 \%$, Russian $-99 \%$, English $-25 \%$. The proportion of the population speaking three languages (state, Russian and English) is 5\%. The proportion of the adult population is nonethnic Kazakhs who speak Kazakh language $-25 \%$. In connection with the research, the electors of the polls in the state language were $36.8 \%$, the electors in Russian $-61.5 \%$, the electors in English $1.7 \%$. Of these, $63.2 \%$ of respondents do not speak Kazakh. National composition of the study participants: Kazakh $-80.0 \%$, Russian $-17 \%$, other $3 \% .72 .7 \%$ of respondents have higher education. Government employees is $11.9 \%$, workers of budgetary organizations and $36.2 \%$, entrepreneurs $-11.7 \%$ of the students of $11.3 \%$, other $28.9 \%$ were not. During the survey, $80 \%$ of respondents noted the Kazakh language as the language of communication.It Russians know that more than a third of respondents $(34.5 \%)$ prefer that education in schools or educational institutions is conducted in Kazakh, about 20\%-in Kazakh and Russian, 42.5\%-in Kazakh, Russian, English and $3.1 \%$-in Russian. Knowledge of other foreign languages is characterized by a small degree. For example, the proportion of people who speak English fluently is very small. Option "I do not know English at all" designated $48 \%$ of the population. Kazakh language is not spoken by $10.1 \%$, and Russian language is not spoken by $1.5 \%$.This is the thesis "do you know other languages?" (except 
as listed). Only $6.5 \%$ of respondents answered this question positively. As additional options, $6.5 \%$ of respondents identified more than 10 languages most commonly used in CIS countries, including German and French.

There is a difference in the level of education by region. Kazakh language occupies a leading position only in the South of Kazakhstan-70.8\% is fluent in reading and writing. In other areas, most respondents are fluent in Russian. A high level of knowledge of the Kazakh language among the regions is observed in Atyrau (100\%) and Zhambyl (85.2\%) regions. According to the state program of development and functioning of languages for 2011-2020 it is provided that till 2025 the population owning the Kazakh language makes $95 \%$.

The influence of the language factor on the use of mass media. Most of the users of Kazakhlanguage media are citizens aged 25 to 40 years living in the South and West of the country. And if you look at the professional level, they are often journalists, civil servants, educators. However, experts do not hide that the audience of users of the Kazakh segment is not fully formed. Thus, in 2016, the share of Kazakh language content in electronic media increased by $12.7 \%$ and amounted to $84 \%$. And the share of Russian-language content decreased by $10.8 \%$ and at the end of the year was $16 \%$. However, the share of electronic media in the total structure is only $16 \%$. The rest is the distribution of information in printed form. The share of Kazakh-language content in it is 50\%. At the end of 2016, 2 thousand 900 mass media were registered in Kazakhstan. Of these, 23\% are state-owned media. $71 \%$ of information of the state mass media in the Kazakh language. In 2015, this figure was $60 \%$. However, as a result of a survey conducted by the Ministry of culture and sports of Kazakhstan, the majority of users reported that the state media in the Kazakh language are not popular and are sites with low information content.

According to the research conducted by the research Institute of strategy of Kazakhstan under the President of Kazakhstan, one third of Kazakhstan citizens have the potential to obtain information in both Kazakh and Russian languages. The population with access to information in two languages is 36.3 per cent of the total population. The total share of those wishing to consume information products in the Kazakh language was $25.5 \%$, including $9.8 \%$ of respondents it became known that the information is consumed only in the Kazakh language. The proportion of citizens wishing to receive information only in the Kazakh language directly depends on the age of the respondents. The older the age, the more the Respondent chose the answer: "I only use information in the Kazakh language". Every third Respondent (33.3\%) and indicated that in the process of obtaining information, the preference for the Russian language. $14.7 \%$ of the citizens surveyed reported that they can understand the information only in Russian [9].

One third of Kazakhstan's citizens have bilingual education, each of which has the potential to obtain information in both Kazakh and Russian languages. The share of such population prevails and is $36.3 \%$ of the total population. The share of young people wishing to receive information in the Kazakh language among Bilingual people was $19.1 \%$ [10].

\section{Promotion and enhancement of the public status of the state language:}

1) Culture - promoting and raising the public status of the state language of culture is the country's influence on the world culture, its tourist attractiveness and sports achievements. It is necessary to implement measures to promote national material and spiritual values, the contribution of the Kazakh people to universal culture, described in the article of the President of the Republic of Kazakhstan N. Nazarbayev "Seven facets of the great steppe";

2) Education - the level and quality of education, the availability of international mutual exchange programs and internships, the number of foreign students in the country. According to the Centre for International Programs, 14,000 foreign students were studying in Kazakhstan in 2018, and their number will reach 50,000 in 2020. Of these, 3,683 are from Uzbekistan, 3,290 from India, 1,320 from Turkmenistan, 1,290 from China and 1,026 from Kyrgyzstan. In addition, there are students who come to the country for short-term internships from Korea, Japan, Turkey and other 
countries. The program should include measures that contribute to Kazakhstan's international standing through the acquisition of the Kazakh language by students from abroad;

3) Economy and innovation - attractiveness, efficiency and availability of development potential of the economic model. Increasing the number of small and medium-sized businesses exporting agricultural products, creating conditions for the promotion of the Kazakh language and Kazakh culture through the brand name of goods and products, specific technology of their manufacture.

\section{Conclusion}

The level of proficiency in the state language in society is ambiguous. This problem aspect, according to experts conducting sociological research, is directly related to the low level of training of teachers and specialists of the Kazakh language, the lack of common standards of the infrastructure of teaching the Kazakh language, the imperfection of the system of stimulation and monitoring of the process of proficiency in the state language. The insufficient introduction of the state language into the social and communicative space of the country is also of concern. Issues in this direction are connected, first of all, with the expansion of the scope of active use of the state language in the field of international communications, recreation and entertainment, its intensive development as the language of law, science and new technologies. However, there is a list of issues, such as raising the status of the use of the state language, its recognition as a family value, especially the problem of language transmission between generations, requires special study, as well as a number of negative aspects and stereotypes in the language sphere. The decline of language culture in the Kazakh society leads to the anxiety of specialists-linguists. On this aspect, the problems in the field of terminology, anthroponomy and onomastics, the need to improve the culture of speech and writing, as well as the creation of a tolerant language environment create serious difficulties for the further development of linguistic space. The need to preserve and strengthen the linguistic capital of Kazakhstan also should not remain without attention in this aspect as a competitive priority of Kazakhstan, along with Kazakh, there is a whole range of problems associated with improving the level of English, creating conditions for the development of ethnic languages that form the linguistic diversity of culture of Kazakhstan, and the study of other foreign languages as an instrument of international business communication.

\section{BIBLIOGRAPHY}

1. Ахметжанова 3. Витальность казахского языка как проблема языкознания и языковой политики // Вестник Павлодарского государственного университета. - 2010. - №1.

2. Сулейменова Э.Д., Мадиева Г.Б., Шаймерденова Н.Ж. Словарь по языкознанию. Алматы: Ғылым, 1998.

3. Уәли Н. Қазақ тілінің мемлекеттік тіл ретінде қызмет етуінің алғышарттары // ҚР ҒА Хабарлары. Тіл-әдебиет сериясы. - 1998. - №3.

4. Момынова Б. Қазақ әдеби тілінің өміршеңдігі // Павлодар Мемлекеттік университетінің хабаршысы. Филология сериясы. - 2010. - №3.

5. Фазылжанова А. «Үштұғырлы тіл» мәдени жобасындағы тілдердің Қазақстан кеңістігіндегі үйлесімді қызметі // «Білім және ғылым саласындағы инновациялар» атты Халықаралық ғылыми-тәжірибелік конференция материалдары. - Алматы, 2011. Б. $172-179$.

6. Фазылжанова А. «Мемлекеттік тіл саясатын жүзеге асырушы органдарға арналған әліпби ауыстырумен байланысты тілтанымдық реформаны жүзеге асырудағы тілдік жағдаят және қауіптерді <ағыл. risk> басқару» жөніндегі талдамалық анықтама. - Алматы, А.Байтұрсынұлы атындағы Тіл білімі институты, 2018. 
7. ҚР БҒМ «Ақпараттық-аналитикалық орталық» АҚ «ҚР білім беру жүйесінің даму жағдайы туралы ұлттық баяндама». - Астана, 2017.

8. «Сорос - Қазақстан» қорының қаржылық/сараптамалық қолдауымен жүргізілген «Тұрмысың қалай, жастар?» атты Қазақстанның әлеуметтанушылар мен саясаттанушылар қауымдастығының (ҚӘСҚ) зерттеу жобасы аясында 2016 жылғы 23 сәуір - 6 мамыр аралығында жастар арасында «Аймақтық жастардың этностық-діни бірегейленуі» атты сауалнаманың нәтижелері бойынша дайындалған есеп. - Астана, 2016.

9. Қазақстан Республикасы Президентінің жанындағы Қазақстан стратегиялық зерттеулер институты «Қоғамдық пікір» институты» ҚБ «Қазақстандағы медиа-тұтынудың қазіргі заманғы тенденциялары» атты аналитикалық жиынтық есебі. - Астана, 2018.

10. Қазақстан Республикасы білім беру жүйесінің жай-күйі және дамуы туралы ұлттық баяндама (Қазақстан тәуелсіздігінің жылдарында) / Қоғамдық пікір зерттеу институты ақпараттық-талдау орталығы. - 2017. [Электронды ресурс]. - Кіру режимі: http://iac.kz/kk/analytics

\section{REFERENCES}

1. Ahmetjanova Z. Vitalnost kazahskogo iazyka kak problema iazykoznaniia i iazykovoi politiki // Vestnik Pavlodarskogo gosudarstvennogo universiteta. - 2010. - №1.

2. Suleimenova E.D., Madieva G.B., Şaimerdenova N.J. Slovar po iazykoznani. - Almaty: Ğylym, 1998.

3. Uáli N. Qazaq tiliniń memlekettik til retinde qyzmet etuiniń alğyşarttary // QR ĞA Habarlary. Til-ádebiet seriiasy. - 1998. - №3.

4. Momynova B. Qazaq ádebi tiliniń ómirşeńdigi // Pavlodar Memlekettik universitetiniń habarşysy. Filologiia seriiasy. - 2010. - №3.

5. Fazyljanova A. «Üştūğyrly til»» mádeni jobasyndağy tilderdiń Qazaqstan keńistigindegi úilesimdi qyzmeti // «Bilim jáne ğylym salasyndağy innovasiialar» atty Halyqaralyq ğylymitájiribelik konferensiia materialdary. - Almaty, 2011. - B. 172-179.

6. Fazyljanova A. «Memlekettik til saiasatyn júzege asyruşy organdarğa arnalğan álipbi auystyrumen bailanysty tiltanymdyq reformany júzege asyrudağy tildik jağdaiat jáne qauipterdi $<$ ağyl. rısk $>$ basqaru» jönindegi taldamalyq anyqtama. - Almaty, A.Baitūrsynūly atyndağy Til bilimi instituty, 2018.

7. $\mathrm{QR}$ BĞM «Aqparattyq-analitikalyq ortalyq» $\mathrm{AQ}$ «QR bilim beru júiesiniń damu jağdaiy turaly ūlttyq baiandama». - Astana, 2017.

8. «Soros - Qazaqstan» qorynyń qarjylyq/saraptamalyq qoldauymen júrgizilgen «Tūrmysyń qalai, jastar?» atty Qazaqstannyń áleumettanuşylar men saiasattanuşylar qauymdastyğynyń (QÄSQ) zertteu jobasy aiasynda 2016 jylğy 23 sáuir - 6 mamyr aralyğynda jastar arasynda «Aimaqtyq jastardyń etnostyq-dini biregeilenui» atty saualnamanyń nátijeleri boiynşa daiyndalğan esep. Astana, 2016.

9. Qazaqstan Respublikasy Prezidentiniń janyndağy Qazaqstan strategiialyq zertteuler instituty «Qoğamdyq pikir» instituty» QB «Qazaqstandağy media-tūtynudyń qazirgi zamanğy tendensiialary» atty analitikalyq jiyntyq esebi. - Astana, 2018.

10. Qazaqstan Respublikasy bilim beru júiesiniń jai-kúii jáne damuy turaly ūlttyq baiandama (Qazaqstan táuelsizdiginiń jyldarynda) / Qoğamdyq pikir zertteu instituty aqparattyq-taldau ortalyğy. - 2017. [Elektrondy resurs]. - Kiru rejimi: http://1ac.kz/kk/analytıcs 